\title{
TECHNOLOGY TRANSFER AND THE CHALLENGES OF LOCAL CONTENT DEVELOPMENT IN THE NIGERIAN OIL INDUSTRY
}

OFFIONG I. AKPANIKA

\begin{abstract}
With over fifty years of oil industry operation in Nigeria, the sector is still largely foreign-technology driven. The national government $\hat{\mathbf{s}}$ involvement has been classified into three distinct era: (1) The Era of Royalty (1956-1970) when government played passive facilitative role limited to the collection of royalties, rents, taxes and other forms of dues from the oil companies; (2) the Era of Shareholding (1971-2004) when petroleum was established as a strategic rational resource which meant that ownership, control and exploitation should be vested in the Federal Government and (3) the Era of Active Involvement (2004-date) in which government seeks greater indigenous involvement through the encouragement of indigenous participation in upstream operations (Marginal Fields Development Programme) and the internalization of input in the industry by increasing the quantum of composite value added or created in the Nigerian economy through the utilization of Nigerian human and material resources (Local Content Development Programme). The latter programme is thus an attempt at circumventing both the capitalist and the critical social theories of technology transfer and developing an indigenous technology initiative. Physical infrastructure and social macroeconomic environment, institutional framework as well as attitudinal changes are identified as critical to the successful Nigerianization of oil industry in Nigeria.
\end{abstract}

KEYWORDS: Technology transfer, challenges, local content development, capitalist and critical social theories.

\section{INTRODUCTION}

The concept of technology transfer has been defined as the movement of know-how, technical knowledge or technology from one organizational setting to another (Bozeman, 2000). The term has also been used to describe a wide range of organizational and institutional interaction involving some form of technologyrelated exchange (Bozeman and Crow 1991). UNESCO (1974) noted that much of the issues of the development or non-development of the Third World countries has been linked with technology transfer from which two theoretical frameworks emerge $\ddot{i}$ one capitalist theoryôand the óritical social theoryô

The former looks at technology as a factor of production which could be sold and bought in the market like other commodities
(UNCTAD, 1972) and regard technology transfer as a short-cut to third world industrialization ï a means by which third world countries can catch up with their developed counterpart if properly pursued. The transnational technocrats and the multi-national companies are thus considered as agents of technology transfer and hence development (Emmanuel, 1982).

On the other hand, the critical social theory interprets the motive behind technology transfer as a form of technical imperialism. The import and acquisition of technology, Akimladun (1976) argued, cannot be considered in isolation from the strategies adopted by its suppliers, particularly the multi-national companies (MNCs) for its exploitation at global level. Thus, where techno-economic structure is inextricably tied to western technology and the production controlled by transnational technocrats as in the Nigerian

Offiong I. Akpanika, Department of Chemical/Petroleum Engineering, University of Uyo, Uyo, Akwa Ibom State, Nigeria. 
Oil Industry, there can be no transfer of technology but rather technological relocation and the resultant under-development is seen as being perpetuated by the structure of technological dependence (Onimode, 1982; 1988).

This no-win (head-or-tail-you-lose) situation has prompted calls for indigenous technology initiative as a development alternative (Kuuya, 1979; Edoho 1990). This paper reviews the changing role of Government in the MNCcontrolled Nigerian Oil Industry and examines the prospects and challenges of the local content development programme of government aimed at Nigerianizing oil technology.

\section{THE NIGERIAN OIL AND GAS INDUSTRY}

NNPC (2004) reports that the Nigerian oil and gas industry dates back to 1905 when evidence of mixed deposit was noticed during a mineral survey at Araromi (present day Ondo State). Actual exploration for oil began in 1908 by the German Bitumen Company. This was interrupted by World War I. World War II (19411945) truncated another effort commenced in 1937 when an oil prospecting licence (OPL) was granted Shell-DôArcy. Exploration, however, returned immediately after the war. Mobil Exploration Nigeria Incorporated joined the search for oil in Nigeria in 1955 with a concession over the whole of the then northern Nigeria. It was not until 1956 that the first commercial find was struck at Oloibiri by Shell with production and export commencing in 1958 (NNPC, 2004).

The growth of the Nigeria Oil Industry has been impressive ï from a humble 5,000 barrels per day at inception to about $2.6 \mathrm{mbpd}$ capacity in 2006. Table 1 shows other characteristic of the Nigeria Oil Industry.

TABLE I: Characteristics of Nigerian Oil Industry

\begin{tabular}{lll}
\hline Reserves & - & 36.200 billion barrels of oil, 167 trillion cubic fat of gas \\
Oil Fields & - & 500 fields $(55 \%$ of these are onshore $)$ \\
Wells & - & $5300(1481$ active $)$ \\
Pipelines & - & $13 \mathrm{~km}$ \\
Terminals & - & 7 \\
Flow Stations & - & 112 \\
FPSO & - & 6 \\
\hline
\end{tabular}

Source: NNPC, 2004.

Technology in the industry has also witnessed considerable development as drilling is extended to the deep water frontiers. Whereas only straight holes with modest deviation from the

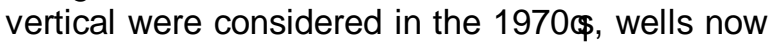
have complex architectures, reaching down to over two miles and horizontal well as long as 7 miles (Kupolokun, 2007). The robust nature of the industry is also seen in the growth in the number of players. By 1963, only five companies were operating in Nigeria. Table 2 shows the oil MNCs along with indigenous companies that have benefited from various forms of licences, leases and concessions in Nigeria. For obvious reasons, the indigenous companies produce about 110,000 bpd representing a dismal $5 \%$ of total output (NNPC, 2007).

\section{GOVERNMENT INVOLVEMENT IN THE INDUSTRY}

Government $\hat{\Phi}$ involvement in the oil industry since its take-off in 1956 has been divided into three phases (Akpanika, 2008). These are:

\section{(1) The Era of Royalty (1956 - 1970)}

When oil was discovered in Nigeria, the country had very little human, technical and financial capability to manage and operate even a sizeable petroleum sector. The MNCs operated in a purely laisse-faire environment with little or no control exercised by the Nigerian government. Government played only a passive, facilitative role limited to the collection of royalties, rents, taxes and other dues from the oil companies. 
The era witnessed influx of foreign investment in the oil sector accounting for up to $92 \%$ of the aggregate foreign investment in Nigeria. Ironically, this was recycled back without much impact on the local economy. Pearson (1970) showed that of N29.2m disbursed by the oil industry to contractors, $82 \%$ went to foreign companies in contrast to $18 \%$ to Nigerian firms.

Table 2: Multinational and Indigenous Companies Operating Various Agreements in the Nigerian Oil Industry

\begin{tabular}{|l|}
\hline Joint Operating \\
\hline $\begin{array}{l}\text { 1. Shell Petroleum Development } \\
\text { Company }\end{array}$
\end{tabular}

2. Mobil Producing Nig Unlimited

3. Chevron Nigeria Limited

4. Elf Petroleum Nigeria Limited

5. Nigerian Agip Oil Company Limited

6. Pan Ocean Oil Corporation (Nigeria)

\section{PSC Companies}

1. Addax Oil Nigeria Limited

2. Statoil Nigeria Limited

3. Shell Nigeria Exploration \& Production Company (SNEPCO) Limited.

4. Addax Petroleum Development (Nigeria) Limited (ADPNL)

5. Addax Petroleum Exploration (Nigeria) Limited (ADPNL)

6. Nigerian Agip Exploration Limited

7. Agip Energy and Natural Resources (Nigeria) Limited

8. Texaco Nigeria Outershelf Limited

9. Star Deep Water Petroleum Limited

10. Chevron Nigeria Deep Water Limited

11. Esso Exploration and Production Nigeria Unlimited

12. Conoco Exploration and Production Nigeria Limited

13. Elf Petroleum Nigeria Limited (EPNL)

14. Petroleo Brasileiro Nigeria

15. Oranto Orandi Petroleum Limited

16. Philips Exploration (Nigeria) Limited

17. Ocean Energy Nigeria Limited

18. ECL International Limited

19. Vintage Oil and Gas

20. Shell Nigeria Ultra Deep Nigeria Limited

\section{Indigenous Licence Holders*}

1. Amni Int $\widehat{\phi}$ Petroleum Dev. Co.

2. Atlas Petroleum International

3. Cavendish Petroleum

4. Conoil Producing Limited

5. Continental Oil and Gas

6. Emerald Petroleum

7. Express Petroleum \& Gas Co.

8. Famfa Oil Limited

9. Moni Pulo Limited

10. Noi East Petroleum Limited

11. Obekpa Petroleum Limited

12. Peak Petroleum Industries

13. Sogal Petroleum Limited

14. South Atlantic Petroleum

15. Yinka Folawiyo Petroleum

Source: NNPC (2004).

* To these can now be added the twenty four indigenous companies operating the Marginal Fields.

Although the oil companies assisted the government in establishing requisite capabilities in creating departments and appropriate curricula for training Nigerians in oil-related technological science and engineering disciplines, Edoho (1990) noted that there is usually a divergence of 
interest between the host government and the foreign companies in the issue of technology transfer. In order to prolong their lucrative role, the foreign companies keep the host developing country in a state of dependence on their services since it is not in their best interest to contribute positively to any process that would eventually enable the host country to dispense with their services partially or completely. Thus, even though the Petroleum Decree No. 58 of 1969 required, in part, that within 10 years from the granting of a licence, the number of Nigerian citizens employed by the organization in connection with the licence in managerial, professional and supervisory grades reach at least $75 \%$ of the total number of persons employed by the operator, this is yet to be achieved and a lot of expatriates are still brought into the country through the Service Companies under several guises (Gidado, 1999).

\section{The Era of Shareholding (1971-2004)}

Progressively the prominence of the oil sector as a vital arm of the economy and its role as a major foreign exchange earner was recognized. The architects of Nigeria⿳⺈ Second National Development Plan (1970-1975) established Petroleum as a strategic national resource. This was interpreted to mean that ownership, control and exploitation should be vested in the Federal Government (FGN, 1970), a stand that was bolstered as Nigeria joined Organization of Petroleum Exporting Countries (OPEC) and became its eleventh member in 1971. OPEC Resolution No. XVI. 90 of 1968 had obligated its members to gradually acquire equity interest in oil MNCs to maximize the financial benefits of member countries. It was believed that if government had more say in the running of the oil industry, it could achieve its goals of rapid industrial and commercial development.
This role was implemented through Decree No. 18 of 1971 which established and institutionalized the Nigerian National Oil Corporation (NNOC) to acquire and manage government $\hat{\Phi}$ interests in the Joint Ventures with Oil MNCs. This period also marked the Nigerianization/Indigenization era in which local operators and service providers started to participate in the capital intensive, high technology oil industry operations in Nigeria. Although this indigenous operatorship has been at various times reinvigorated through the allocation of blocks to indigenous companies to operate on a sole-risk basis, the input of these local firms in providing services are in total less than $10 \%$.

The NNOC transformed in 1977 by Decree No. 33 to Nigerian National Petroleum Corporation (NNPC) and was re-organized ten years later as a commercial integrated oil company with the mission to ñprofitably explore, develop, produce, process and market crude and refined petroleum and their by-products and derivatives both at home and abroadò Today it will hardly be an understatement to say that NNPC has not accomplished this mission. It has remained a r̃sleeping partnerò in all the Joint Venture partnerships. The economy has not been any better, the oil industry still remains an enclave with little or no multiplier effects on the economy as the MNCs continue to exercise oligopolistic control over all aspects of oil technology from exploration, production and refining to marketing.

Contract dispensing pattern remains the same with massive capital flight (Table 3 ) not just via contracts but remuneration for foreign expatriate labour, payment for training and development programmes outside Nigeria, equipment procurement abroad and importation of software and data monitoring systems (Nwosu et al, 2006). 
Table 3: Contract Value of Major contracts in Nigerian Oil and Gas Companies by location of the Contracted Company $\hat{\Phi}$ Value Addition activities and ownership in different activity categories, 1000 USD (2002).

\begin{tabular}{|c|c|c|c|c|c|}
\hline & \multicolumn{2}{|c|}{$\begin{array}{l}\text { Companies with significant } \\
\text { value addition in Nigeria }\end{array}$} & \multicolumn{2}{|c|}{$\begin{array}{l}\text { Companies with significant } \\
\text { value addition abroad }\end{array}$} & \multirow[b]{2}{*}{ TOTAL } \\
\hline & $\begin{array}{l}\text { Nigerian } \\
\text { Owned }\end{array}$ & $\begin{array}{l}\text { Foreign } \\
\text { Owned }\end{array}$ & $\begin{array}{l}\text { Nigerian } \\
\text { Owned }\end{array}$ & $\begin{array}{l}\text { Foreign } \\
\text { Owned }\end{array}$ & \\
\hline Consultancy & 7428 & 0 & 2778 & 0 & 10,206 \\
\hline $\begin{array}{l}\text { Drilling \& Well } \\
\text { Completion }\end{array}$ & 42847 & 135939 & 35091 & 593284 & 807,161 \\
\hline $\begin{array}{l}\text { Environmental } \\
\text { Services }\end{array}$ & 11018 & 0 & 6533 & 9250 & 26,801 \\
\hline Exploration & 1262 & 11056 & 0 & 90413 & 102,731 \\
\hline FEED & & & 0 & 40577 & 40,577 \\
\hline Gas Development & 0 & 0 & 0 & 27978 & 27,978 \\
\hline Hotel \& Catering & 11760 & 0 & 5454 & 31637 & 48,851 \\
\hline & 17107 & 526 & 11328 & 17520 & 46,481 \\
\hline Procurement & 26356 & 1062 & 62105 & 92248 & 181,771 \\
\hline $\begin{array}{l}\text { Production \& Facility } \\
\text { Maintenance }\end{array}$ & 12367 & 2656 & 62375 & 75243 & 152,641 \\
\hline $\begin{array}{l}\text { Projects/Construction } \\
\text { EPC }\end{array}$ & 82253 & 269778 & 28193 & 657668 & $1,037,892$ \\
\hline Transportation & 18,143 & 61,275 & 63,155 & 234,515 & 377,088 \\
\hline TOTAL & 230,541 & 482,292 & 277,012 & $1,870,333$ & $2,860,178$ \\
\hline Percentage of Total & $8 \%$ & $17 \%$ & $10 \%$ & $65 \%$ & $100 \%$ \\
\hline $\begin{array}{l}\text { Average Spent on } \\
\text { each Contractor }\end{array}$ & 4210 & 20100 & 1380 & 11200 & \\
\hline
\end{tabular}

\section{Era of Active Involvement (2004-date)}

Following a country-wide outcry for greater indigenous involvement in the oil sector as a means of raising the average standard of living, government seeks to harness the expertise of the large pool of high-level technically competent oil and gas industry workers created over the fifty years of the industry in the country through two cardinal programmes i Marginal Field Development Programme (MFDP) and the Local Content Development Programme (LCDP). While the former seeks the development of independent indigenous operators through the encouragement of small-scale indigenous investors that had no previous opportunities in making investment in the upstream sector of the petroleum industry, the latter seeks the promotion of the internalization of inputs in the upstream sector by increasing the quantum of composite value added or created in the Nigerian economy through the utilization of Nigerian human and material resources for the provision of goods and services to the petroleum industry (NNPC 2004).

Using a three-prong approach, Ogbeifun (2004) defines the local content concept as the engagement of Nigerians as employees, the participation of Nigerian investors in the industry and the use of Nigerian contractors in the execution of contracts. The overall vision is to transform the oil and gas industry into the economic engine for job creation and national growth by developing in-country capacity and indigenous capabilities. Thus a greater proportion of the oil industry work will be done in Nigeria with active participation of all sectors of the economy.

\section{LOCAL CONTENT PERFORMANCE INDICATORS}

The targets set by the Federal government for Nigerian content in oil industry operations is $45 \%$ by 2006 and $70 \%$ by 2010 . As part of the organizational framework for the implementation of the policy, a Nigerian Content Division headed by a Group General Manager was wet up in NNPC in 2005. A Nigerian Content Consultative Forum (NCCF) was also inaugurated with 8 sectorial working Committees covering Fabrication engineering, Manufacturing, 
Banking and Finance, Shipping \& Marine, Well Drilling as well as Logistic Services.

An inventory of E\&P technologies grouped into 17 major areas and weighted on:

(a) Potential contribution to new Nigerian employment both directly and indirectly and (b) Potential for increased share of locally manufactured equipment from Nigerian supply and Service industry show that work related to fabrication and well completion stand out as potentially strong contributors to increased local content delivery (Fig 1).

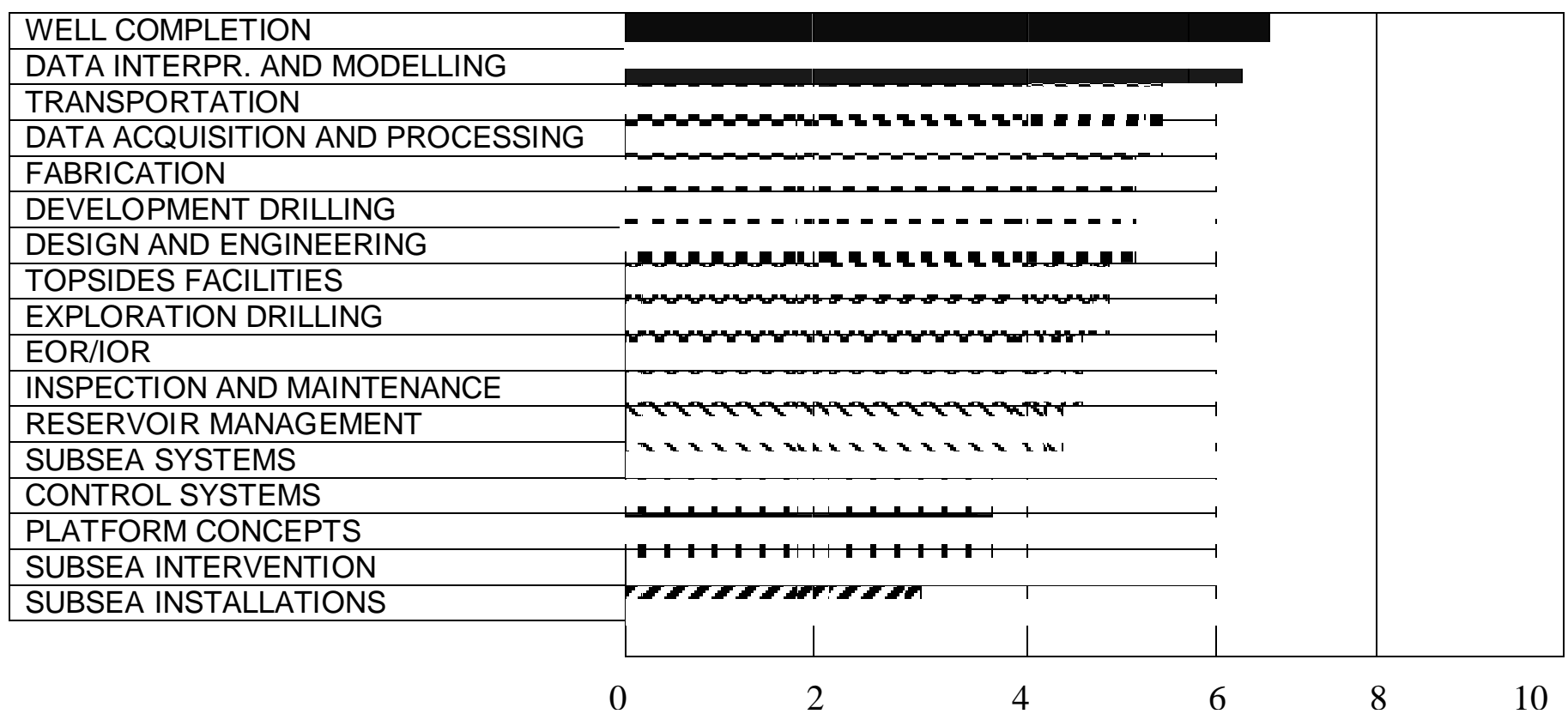

Figure 1: Technology areas ï Current level of competence.

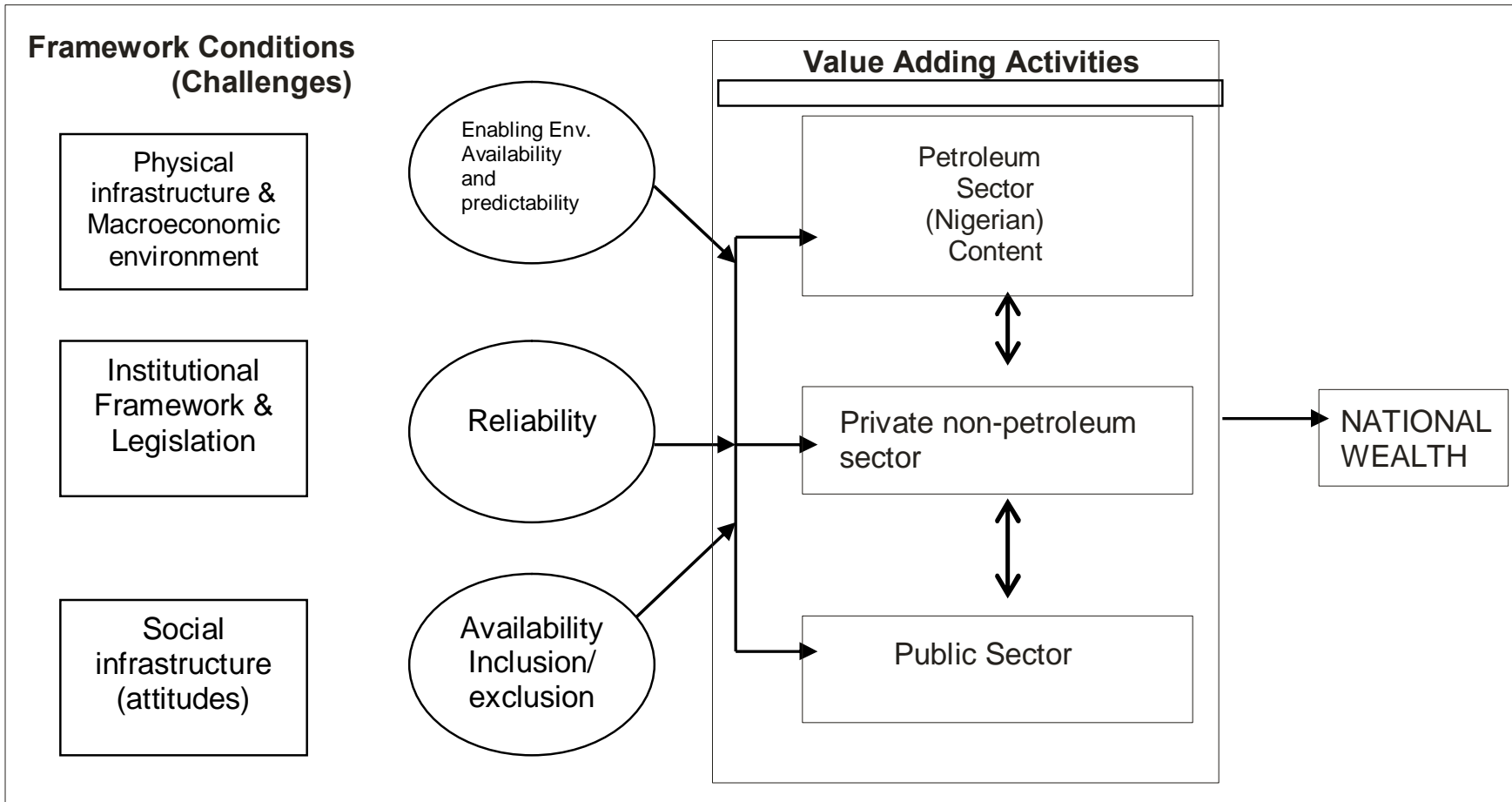

Figure 2: A comprehensive perspective on industrial growth and national wealth (after Abgamu, 2005 
Since the implementation of the LCDP more than 6.5 million man-hours of engineering have been domiciled in-country with more than $225,000 T$ of fabrication compared to 25000T of the pre-local content days (NNPC, 2008). Also Foreign Direct Investment for manufacturing of oil and gas pipes, setting up of Oil Country Tubular Goods (OCTG) threading plants and for Xmas Trees in-country has been attracted as well as increased Engineering services Agreements between MNCs and Local Engineering Companies.

\section{CHALLENGES}

The ultimate goal of a viable local content policy is to create a multiplier effect on the economy thus enhancing sustainable growth and national wealth. Three key challenges identified in the sustainable development of the local content policy are:

- Physical Infrastructure macroeconomic challenge

- Institutional challenge and

- Social infrastructure \& attitudinal challenge which form the perspective for industrial growth and national wealth.

\section{Infrastructure and macro-economic} environment

The success of the local content policy will depend to a large extent not just on the protection for domestic firms as envisaged in the various orders and directives to multi-national oil companies, but on efforts that can facilitate the participation of domestic firms in the petroleum activities on a competitive basis. This will involve creating a more predictable macroeconomic environment as well as having strong manufacturing and industrial sector as well as some social re-engineering. Translated, this means improved power supply, steel manufacture and ancillaries, like efficient transportation, communication and basic amenities. Neff (2005) has noted that a stable and efficient overall economic and business climate in a country is sine qua non to its local content development programme.

\section{Institutional challenge}

When oil was first discovered in Nigeria the country had very little human resources, technical and financial capability to manage and operate even a sizeable modern petroleum sector (Chima et al, 2002). Agreements for exploration and exploitation were signed between the MNCs and the British Government and regulations for operation were mainly from the Colonial Office.

The major indigenous legislation for operation of the Nigerian Oil Industry is the Petroleum (Regulation) Act of 1969. This was before Nigeria joined OPEC and began to show active interest in the industry. There is therefore a strong need for a reformation of the sector through legislations for effective and improved regulation of the sector which currently suffers duplicated (and sometimes conflicting) roles within regulatory authorities. Regulations ought to be strictly separated from business operations.

\section{(3) Social Infrastructures and Attitudinal Change}

A pre-requisite for the success of any policy is that Decision Makers at all levels in the society share the goals of pursuing the tenets of the policy. There is no denying the fact that in Nigeria, there exist a bureaucratic comprador (a mafia of sort). Sadly, this is the very group saddled with the responsibility of implementing polices. Fueled by their aggrandizement, selfishness and greed, they maintain a triangular relationship with m̃middle men and foreign suppliers, continually strengthening the commercial bourgeoisie to the detriment of genuine entrepreneurs with considerable inclination to manufacturing and production. The comprador group sets out to cut corners to milk the system to the disadvantage of the nation and in some cases engage in sinister sabotage of policies they cannot influence or benefit from. This corporate corruption (corruption in Grighplacesô must be tackled vigorously.

Industrial growth and national wealth can only be guaranteed when framework conditions (challenges) are translated to value adding activities through the creation of enabling environment, reliable institutional frameworks and legislations as well as the existence of right social attitudes (Fig 2).

The fifty years of oil industry operation has produced for Nigeria a large crop of technically competent and experienced workforce that could champion the success of the Local Content Development Programme. The bane of this group, however, is the done-star syndromeò Rather than partner with colleagues to form strong companies that could easily attract financing, government and industry recognition, they go alone, forming low equity base companies, usually owner-managed, that are 
incapable of meeting the titanic financial commitment involved in the industry. They thus end up working in isolation as ćonsultantsôand suppliers of goods requiring little or no value addition or at best enter into weak alliances with foreign companies in which they become mere ódgentsô

Local entrepreneurs should therefore be encouraged to put resources together as partnerships, cooperative enterprises or new limited liability entities registered under special job categories. This will provide a strong base and help them have access to funds to enable them improve their skills in research, design, development, manufacturing, quality control and marketing.

\section{CONCLUSION}

To secure the long-term welfare for its citizenry through the transformation of its natural endowment is the challenge of every nation. Indeed the performance of Nigeria over the past five decades clearly reveals that we have not succeeded in transforming the oil wealth into a broader based industrial wealth.

The mainstreaming of indigenous concerns and resources in the conceptualization, design and implementation of national development effort forms the veritable step in technology acquisition. Local participation, through the local content development programme, will hopefully facilitate economic growth and national development through

- reduction in capital ólightôabroad,

- employment generation

- creation of better infrastructure in society

- local skills enhancement and

- value added to the local economy.

In order to achieve these laudable goals, government should vigorously pursue the needed reforms in the oil industry, evolve a strategy to identify and support the most likely opportunities to build and expand domestic capability and employment. Government must also provide the infrastructure and enabling environment for the emergence of a vibrant indigenous entrepreneurship knowing that value addition does not develop by decrees but when local industrial capacity is sufficiently developed.

\section{REFERENCES}

Agbamu, S. O., 2005. Sustenance of Nigerian (Local) Content Development Policy in the Oil and Gas Industry. Proceedings of National Engineering Conference and AGM. Karo 2005. 202-208.

Akimolodun, R. O., 1976. Oil in Nigeria: A study in Political Economy of Underdevelopment. Unpublished Ph.D dissertation. Department of Political Sciences. Howard University, USA.

Akpanika, O. I., 2008. Challenges of Sustainable Local Content Development in the Nigerian Oil Industry. Offshore West Africa Ф8 Conference \& Exhibition. Jan. 29-Feb. 02, Abuja, Nigeria.

Bozeman, B., 2000. Technology Transfer and Public Policy: A review of Research and Theory. Research Policy 29, 627-655.

Bozeman, B and Crow, M., 1991 Technology Transfer from US Government and University $R$ \& $D$ Laboratories. Technovation 11, (4): 231.

Chima, R. I., Onwioduokit, E. A and Ogoh, E. A., 2002. Technology transfer and Acquisition in the Oil Sector and Government Policy in Nigeria. ATPS, Working Paper Series (32): 49.

Edoho, F. M., 1990. Technology transfer and Third world Development: The Petrochemical Complex in Nigeria. Bull. Sc. Tech \& Soc 10, 201-211.

EIA., 2006. Country Analysis Briefs: Nigerian http://www.eia.doc.gov/emeu/cabs/nigeri a pdf(contains links to a number of relevant web sites).accessed 14/08/2010

Emmanuel, A., 1982. Appropriate or Underdeveloped Technology? John Wiley and Sons New York 233.

Federal Government of Nigeria., 1970. Second National Development Plan 1970-1974. (Programme of Post War Reconstruction and Development). Federal Ministry of Information, Lagos, Nigeria.

Heum, P., Quale, C., Karlsen, J. E., Kragha, M and Osahon, G., 2003. Enhancement of Local Content in the Upstream Oil ad Gas Industry in Nigeria. A comprehensive and 
Viable Policy approach. SNF Report No. 25/03. 76 .

Kupolukun, G., 2007. Evolution of NNPC/Oil Industry Challenges. NNPC Mag. 4, (3): 7-11.

Kuuya, P. M., 1979. Transfer of Technology: An Overview of Tanzanian Case in Technology and Industrialization in Africa. F. Yaschir (ed.) CODESRIA Book Series, Senegal.

Neff, S., 2005. Memorandum on International Best Practices in Development of Local Content in the Energy Sector. Goldwyn Int. Strategies LLC. Washington DC. 44.

NNPC., 2004. The Nigerian Oil and gas Industry. 66.

NNPC., 2007. Annual Report, Inspectorate Division, Lagos, Nigeria.

NNPC., 2008. Annual Report.
Nwosu, H. U., Nwachukwu, I. N., Ogaji, S. O. T and Robert, S. D., 2006. Local Involvement in Harnessing Crude Oil and Natural Gas In Nigeria. Applied Energy 83, (11): 12741287.

Ogbeifun, B., 2004. How Content is Local Content? www.ganji.com.

Onimode, B., 1982. Imperialism and Underdevelopment of Nigeria. Dialetics of Mass Poverty. Zed Press London.

Onimode, B., 1988. A Political economy of African Crisis. Zed Book Ltd, New Jersey.

UNCTAD., 1972. Guidelines for the study of the Transfer of Technoloy to Developing Countries. United Nations, New York.

UNESCO., 1974. Science and Technology in African Development. Doc. No. XXXV. 